\title{
The effect of exercise on the venous blood ammonium concentration in man
}

\author{
D. SINNIAH ${ }^{1}$, T. T. FULTON, AND H. MCCULLOUGH \\ From the Royal Victoria Hospital, Belfast, Northern Ireland
}

SYNOPSIS Mild muscular exercise did not cause any significant rise in the ammonium 9 concentration of venous blood draining the exercising forearm of control subjects or patients with cirrhosis. However, in both cirrhotic and non-cirrhotic subjects moderate exercise pro-o duced significant increases in venous blood ammonium values and these occurred earlier and $\stackrel{\Phi}{\square}$ were more prolonged in cirrhotic patients. Severe exercise caused larger increases in venous $\stackrel{\mathbb{\Phi}}{\square}$ blood ammonium concentration in all subjects but there were no significant differences between the mean ammonium concentrations of the cirrhotic and control groups either $\overrightarrow{0}$ before or after exercise. All ammonium values returned to their pre-exercise levels within half an hour of resting.

The exact mechanism of these phenomena is not fully understood but they are of practical importance in the study of blood ammonium metabolism in normal subjects and in patients with cirrhosis of the liver. The importance of making subjects rest for at least 30 minutes $\stackrel{D}{\circ}$ before obtaining blood for ammonium determination is emphasized in order to obviate misleadingly high readings due to muscular activity.

As long ago as 1925 Luck, Thacker, and Marrack found elevated venous blood ammonium levels in epileptic patients following grand mal seizures but could not ascribe this effect to muscular contractions because of their inability to show that vigorous muscular activity raised the blood ammonium level. In 1927 Parnas, Mozolowski, and Lewinskiw found that the ammonium concentration in venous blood obtained from the exercising forearm of normal subjects was increased and concluded that fatiguing exercise was responsible for this rise. These observations were later confirmed by Kalk and Boris (1933). In 1958 Schwartz, Lawrence, and Roberts showed that vigorous general exercise resulted in raised blood ammonium levels in normal subjects and that the increases in arterial ammonium levels caused by induced convulsions could be prevented by suppression of the muscular contractions. Bessman and Bessman (1955) and Bessman and Bradley

'Present address: Department of Paediatrics, University of Malaya, Kuala Lumpur, Malaysia.

Received for publication 15 April 1970.
(1955) drew attention to the importance of peripheral tissues in ammonium metabolism. They showed that as the arterial ammonium concentration rises in patients with hepatic en- $₹$ cephalopathy, the peripheral tissues take up음 correspondingly larger amounts of ammonium. These findings were later confirmed by Summerskill, Davidson, Dible, Mallory, Sherlock, N Turner, and Wolfe (1960) and by Webster and Gabuzda (1958), who also noted that in the terminal stages of liver disease the peripheral $\omega$ tissues may liberate ammonium into the systemic venous circulation.

In 1960 Allen and Conn showed that mild exercise resulted in an increase in the ammonium? concentration of blood draining the exercising forearm of cirrhotic patients but not of normal $\stackrel{\circ}{\Phi}$ subjects. More severe muscular exercise caused a@ significantly greater increase in the venous $\varrho$ ammonium level in cirrhotic patients than in non-cirrhotic subjects. Severe fatiguing exercise resulted in large elevations which were approxi-o mately equal in cirrhotic and non-cirrhotic subjects. 
The present investigation was undertaken to study the effects of mild, moderate, and severe forearm exercise on venous blood ammonium concentrations of normal subjects and patients with cirrhosis.

\section{Materials and Methods}

Fifteen control subjects and 15 patients with cirrhosis took part in this investigation. All subjects were studied in the supine position after they had rested for a compulsory minimum period of 30 minutes. None of them had undertaken strenuous muscular exercise before the test nor were they permitted to clench their fists during the period of rest.

Forearm exercise entailed the use of a spring type hand-grip exerciser. Mild exercise consisted of 20 'power grips' at the rate of one per second. Forty 'power grips' constituted moderate exercise and 80 'power grips' severe exercise. Venous blood samples were withdrawn from an ante cubital vein through an indwelling heparinizedP needle immediately before starting forearm exer 0 cise and at intervals of $0,1,3,6,10,15$, and 30 : minutes after exercise, care being taken eachs time to discard the first small portion of bloot before collecting the sample for analysis. Pularin heparin, $500 \mathrm{IU}$ in $2 \mathrm{ml}$ normal saline, was used tơf prevent clotting in the indwelling needle.

Venous blood ammonium levels were estimatedo in all cases by the direct colorimetric method of McCullough (1967). In this method ammonia is determined using the indophenol reaction, the test being carried out on a deproteinized tungstatee sulphuric acid extract of whole blood. The im? mediate treatment of blood samples by protein precipitant renders them stable for up to one hour ${ }_{i o b}^{\omega}$ while subsequent centrifugation and separation of the supernatant permits storage in deep freezer for much longer periods before final analysis musp be undertaken. The procedure is simple, rapid, and specific, and is suitable for serial or multiplez estimations.

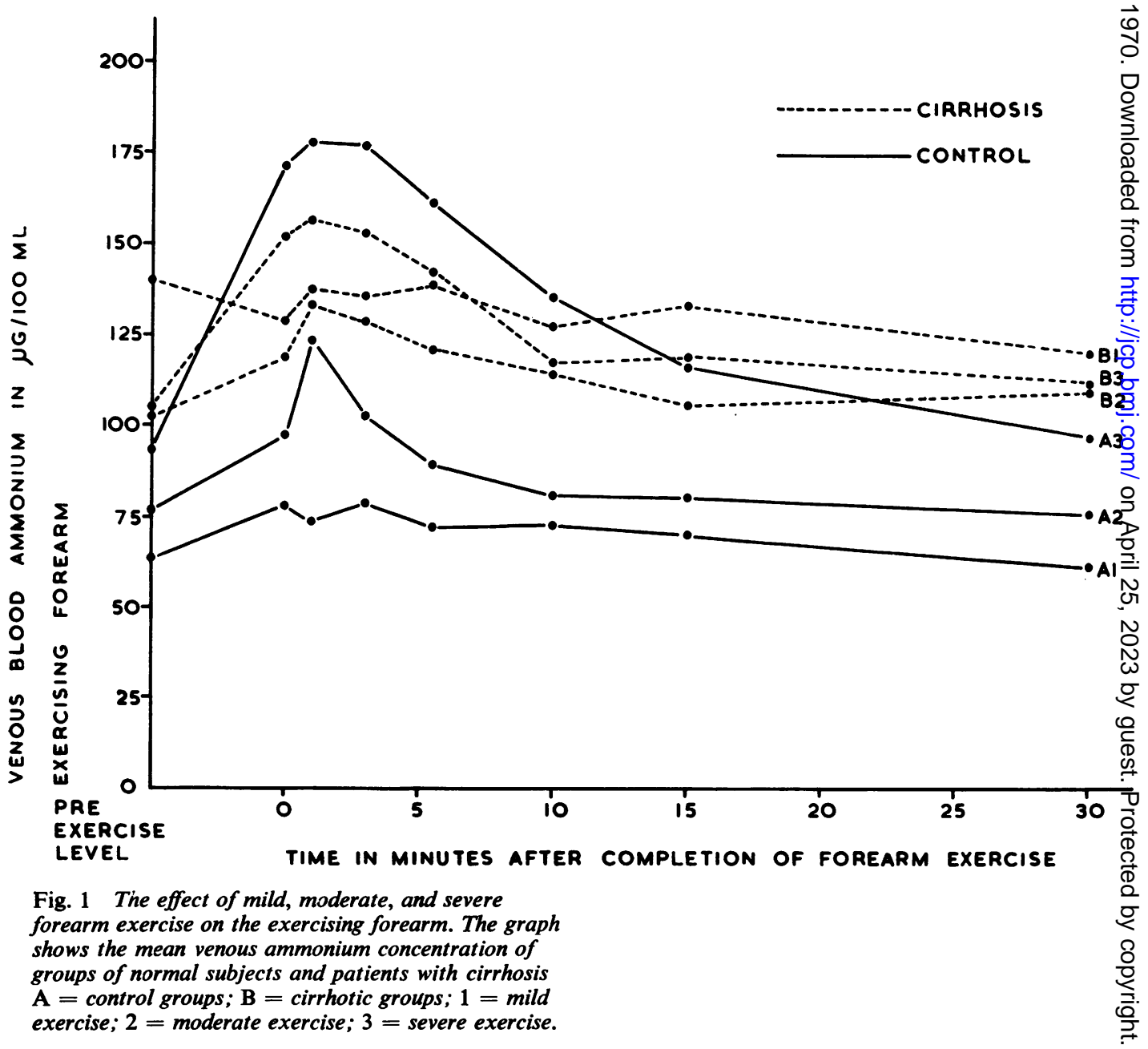




\section{Results}

The results are recorded in Table I and Fig. 1, all ammonium values being expressed as micrograms of ammonia nitrogen $/ 100 \mathrm{ml}$ blood.

\section{MILD EXERCISE}

Five control subjects and five patients with cirrhosis undertook this test. An analysis of variance showed no significant difference between the mean blood ammonium concentrations recorded before and at set intervals after completion of forearm exercise in either the control group or the cirrhotic group $(P>0.05$ and $P>0.05$ respectively). Mild forearm exercise did not therefore produce any significant elevation of the post-exercise blood ammonium concentration above the pre-exercise level in either control subjects or patients with cirrhosis (Table II) Although there were significant differencesp between the ammonium concentrations of indi vidual control subjects no such differences were. noted between those of individual cirrhotic: patients $(P<0.01 \text { and } P>0.05 \text { respectively })_{0}^{\circ}$ Comparison of the mean ammonium values of control subjects and cirrhotic patients showec that significantly higher values were recorded in the cirrhotic group both before and at set times after completion of forearm exercise but th\% differences were of the same order throughout the duration of the test (Table III).

\section{MODERATE EXER CISE}

The effect of 40 'power grips' was studied in fivę control subjects and five cirrhotic patients. Aip analysis of variance of the results obtained

\begin{tabular}{|c|c|c|c|c|c|c|c|c|c|c|c|}
\hline \multirow[t]{3}{*}{ Group } & \multirow{3}{*}{$\begin{array}{l}\text { Type of } \\
\text { Exercise }\end{array}$} & \multirow{3}{*}{$\begin{array}{l}\text { No. of } \\
\text { Observutions }\end{array}$} & \multicolumn{8}{|c|}{ Mean Venous Blood Ammonium Levels in $\mu \mathrm{g} / 100 \mathrm{ml}$} & 7 \\
\hline & & & \multirow{2}{*}{$\begin{array}{l}\text { Before } \\
\text { Exercise }\end{array}$} & \multicolumn{7}{|c|}{ After Exercise } & (1) \\
\hline & & & & $0 \min$ & $1 \min$ & $3 \min$ & $6 \min$ & $10 \min$ & $15 \min$ & $30 \mathrm{~min}$ & $\vec{\nabla}$ \\
\hline $\begin{array}{l}\text { Control } \\
\text { Cirrhosis }\end{array}$ & $\begin{array}{l}\text { Mild } \\
\text { Mild }\end{array}$ & $\begin{array}{l}5 \\
5\end{array}$ & $\begin{array}{r}63 \cdot 2 \\
139 \cdot 8\end{array}$ & $\begin{array}{r}79 \cdot 2 \\
128 \cdot 8\end{array}$ & $\begin{array}{r}74 \cdot 8 \\
137 \cdot 4\end{array}$ & $\begin{array}{r}80 \cdot 0 \\
136 \cdot 8\end{array}$ & $\begin{array}{r}72 \cdot 6 \\
138 \cdot 4\end{array}$ & $\begin{array}{r}74 \cdot 2 \\
127 \cdot 6\end{array}$ & $\begin{array}{r}71 \cdot 4 \\
133 \cdot 8\end{array}$ & $\begin{array}{r}63 \cdot 2 \\
120 \cdot 4\end{array}$ & $\vec{v}$ \\
\hline $\begin{array}{l}\text { Control } \\
\text { Cirrhosis }\end{array}$ & $\begin{array}{l}\text { Moderate } \\
\text { Moderate }\end{array}$ & $\begin{array}{l}5 \\
5\end{array}$ & $\begin{array}{r}75 \cdot 6 \\
101 \cdot 2\end{array}$ & $\begin{array}{r}97 \cdot 8 \\
119 \cdot 4\end{array}$ & $\begin{array}{l}123 \cdot 8 \\
133 \cdot 0\end{array}$ & $\begin{array}{l}103 \cdot 0 \\
129 \cdot 8\end{array}$ & $\begin{array}{r}88 \cdot 4 \\
120 \cdot 4\end{array}$ & $\begin{array}{r}80 \cdot 4 \\
115 \cdot 6\end{array}$ & $\begin{array}{r}80 \cdot 2 \\
107 \cdot 0\end{array}$ & $\begin{array}{r}76 \cdot 2 \\
110 \cdot 6\end{array}$ & \\
\hline $\begin{array}{l}\text { Control } \\
\text { Cirrhosis }\end{array}$ & $\begin{array}{l}\text { Severe } \\
\text { Severe }\end{array}$ & $\begin{array}{l}5 \\
5\end{array}$ & $\begin{array}{r}932 \\
104 \cdot 6\end{array}$ & $\begin{array}{l}170 \cdot 8 \\
151 \cdot 4\end{array}$ & $\begin{array}{l}177 \cdot 8 \\
156 \cdot 8\end{array}$ & $\begin{array}{l}177 \cdot 6 \\
154 \cdot 8\end{array}$ & $\begin{array}{l}161 \cdot 2 \\
142 \cdot 8\end{array}$ & $\begin{array}{l}135 \cdot 2 \\
117 \cdot 2\end{array}$ & $\begin{array}{l}1184 \\
118 \cdot 6\end{array}$ & $\begin{array}{r}98 \cdot 4 \\
112 \cdot 0\end{array}$ & $\stackrel{\partial}{\partial}$ \\
\hline
\end{tabular}

Table I Mean venous blood ammonium levels in groups of control and cirrhotic subjects before and after mildo moderate, and severe forearm exercise

\begin{tabular}{|c|c|c|c|c|c|c|c|c|}
\hline \multirow[t]{2}{*}{ Group } & \multirow[t]{2}{*}{$\begin{array}{l}\text { Type of } \\
\text { Exercise }\end{array}$} & \multicolumn{7}{|c|}{$\begin{array}{l}\text { Difference between Mean Pre- and Post-exercise Blood Ammonium Levels } \pm S E \text { of Difference in } \mu \mathrm{g} / 100 \mathrm{ml} \text { at } \\
\text { Different Times after Forearm Exercise }\end{array}$} \\
\hline & & $O \min$ & $1 \mathrm{~min}$ & $3 \mathrm{~min}$ & $6 \mathrm{~min}$ & $10 \mathrm{~min}$ & $15 \mathrm{~min}$ & $30 \mathrm{~min}$ \\
\hline Control & $\begin{array}{l}\text { Mild } \\
\text { Moderate } \\
\text { Severe }\end{array}$ & $\begin{array}{l}16 \cdot 0 \pm 9 \cdot 3 \\
22 \cdot 2 \pm 14 \cdot 7 \\
77 \cdot 6 \pm 18 \cdot 0^{1}\end{array}$ & $\begin{array}{l}11 \cdot 6 \pm 9 \cdot 3 \\
48 \cdot 2 \pm 14 \cdot 7^{1} \\
84 \cdot 6 \pm 18 \cdot 0^{1}\end{array}$ & $\begin{array}{l}16 \cdot 8 \pm 9 \cdot 3 \\
27 \cdot 4 \pm 14 \cdot 7 \\
84 \cdot 4 \pm 18 \cdot 0^{1}\end{array}$ & $\begin{array}{c}5 \cdot 4 \pm 9 \cdot 3 \\
12 \cdot 8 \pm 14 \cdot 7 \\
68 \cdot 0 \pm 18 \cdot 0^{1}\end{array}$ & $\begin{array}{c}11 \cdot 0 \pm 9 \cdot 3 \\
4 \cdot 8 \pm 14 \cdot 7 \\
42 \cdot 0 \pm 18 \cdot 0^{1}\end{array}$ & $\begin{array}{r}8 \cdot 0 \pm 9 \cdot 3 \\
4 \cdot 6 \pm 14 \cdot 7 \\
25 \cdot 2 \pm 18 \cdot 0\end{array}$ & $\begin{array}{r}0 \pm 9 \cdot 3 \\
0.6 \pm 14 \cdot 7 \\
5.2 \pm 18.0\end{array}$ \\
\hline Cirrhosis & $\begin{array}{l}\text { Mild } \\
\text { Moderate } \\
\text { Severe }\end{array}$ & $\begin{array}{r}-11 \cdot 0 \pm 18 \cdot 1 \\
18 \cdot 2 \pm 7 \cdot 5^{1} \\
47 \cdot 2 \pm 10 \cdot 6^{1}\end{array}$ & $\begin{array}{l}-2 \cdot 4 \pm 18 \cdot 1 \\
31 \cdot 8 \pm 7 \cdot 5^{1} \\
52 \cdot 4 \pm 10 \cdot 6^{1}\end{array}$ & $\begin{array}{l}-3.0 \pm 18.1 \\
28.6 \pm 7.5^{1} \\
50.4 \pm 10.6^{1}\end{array}$ & $\begin{array}{c}-1.4 \pm 18 \cdot 1 \\
19 \cdot 2 \pm 7 \cdot 5^{1} \\
38.4 \pm 10.6^{1}\end{array}$ & $\begin{array}{r}-12.2 \pm 18.1 \\
15.4 \pm 7.5 \\
12.6 \pm 10.6\end{array}$ & $\begin{array}{r}-6 \cdot 0 \pm 18 \cdot 1 \\
5 \cdot 8 \pm 7 \cdot 5 \\
14 \cdot 2 \pm 10 \cdot 6\end{array}$ & $\begin{array}{r}-19.4 \pm 18.1 \\
9.4 \pm 7.5 \\
7.6 \pm 10.6\end{array}$ \\
\hline
\end{tabular}

Table II Comparison of pre- and post-exercise mean venous blood ammonium levels in groups of control subjects and cirrhotic patients

${ }^{1}$ Significant at 0.05 probability

\begin{tabular}{|c|c|c|c|c|c|c|c|c|}
\hline \multirow{3}{*}{$\begin{array}{l}\text { Type of } \\
\text { Exercise }\end{array}$} & \multicolumn{8}{|c|}{ Cirrhosis minus Control Group Readings \pm Standard Error of the Difference in $\mu \mathrm{g} / 100 \mathrm{ml}$} \\
\hline & \multirow{2}{*}{$\begin{array}{l}\text { Before } \\
\text { Exercise }\end{array}$} & \multicolumn{7}{|l|}{ After Exercise } \\
\hline & & $0 \min$ & $1 \min$ & $3 \min$ & $6 \mathrm{~min}$ & $10 \mathrm{~min}$ & $15 \mathrm{~min}$ & $30 \min$ \\
\hline $\begin{array}{l}\text { Mild } \\
\text { Moderate } \\
\text { Severe }\end{array}$ & $\begin{array}{l}76.6 \pm 19.0 \\
25.6 \pm 20.8 \\
11.4 \pm 27.8\end{array}$ & $\begin{array}{r}49.6 \pm 19.0 \\
21.6 \pm 20.8 \\
-19.4 \pm 27.8\end{array}$ & $\begin{array}{r}62.6 \pm 19 \cdot 0^{1} \\
9 \cdot 2 \pm 20.8 \\
-21.0 \pm 24.8\end{array}$ & $\begin{aligned} 56 \cdot 8 & \pm 19 \cdot 0^{1} \\
26.8 & \pm 20 \cdot 8 \\
-22.8 & \pm 24 \cdot 8\end{aligned}$ & $\begin{array}{r}65.8 \pm 19.0^{1} \\
32.0 \pm 20.8 \\
-18.4 \pm 24.8\end{array}$ & $\begin{array}{r}53.4 \pm 19.0^{1} \\
35 \cdot 2 \pm 20.8 \\
-18.0 \pm 24.8\end{array}$ & $\begin{array}{c}62 \cdot 4 \pm 19 \cdot 0^{1} \\
26 \cdot 8 \pm 20 \cdot 8 \\
0 \cdot 4 \pm 24 \cdot 8\end{array}$ & $\begin{array}{l}57 \cdot 4 \pm 19 \cdot 0^{1} \\
34 \cdot 4 \pm 20 \cdot 8 \\
13 \cdot 6 \pm 24 \cdot 8\end{array}$ \\
\hline
\end{tabular}

Table III Comparison of pre- and post-exercise mean venous blood ammonium levels in groups of control subjects and cirrhotic patients

${ }^{1}$ Significant at 0.05 probability. 
showed significant differences between the mean blood ammonium concentrations in both the control group and the cirrhotic group at the different times of sampling $(P<0.05$ and $P<0.01$ respectively). There was also a significant elevation of the mean venous blood ammonium concentration in the control group one minute after completion of exercise and in the cirrhotic group 0 , one, three, six, and 10 minutes after completion of exercise (Table II). No significant differences were found between the mean venous ammonium levels of control subjects and cirrhotic patients either before or at the set times after moderate forearm exercise (Table III).

\section{SEVERE EXERCISE}

The effect of 80 'power grips' was studied in five control subjects and in five patients with cirrhosis. Analysis of variance of the results obtained showed significant differences between the mean blood ammonium concentrations in both the control group and the cirrhotic group at the different times of sampling $(P<0.01$ and $P<0.01$ respectively).

In the control group significant elevations of the mean venous blood ammonium levels above the pre-exercise levels were noted at 0 , one, three, six, and 10 minutes after exercise and in the cirrhotic group at 0 , one, three, and six minutes after exercise (Table II). Comparisons of the mean preexercise and post-exercise blood ammonium concentrations in the control group with those in the cirrhotic group did not show any significant differences (Table III).

No significant differences between the preexercise and 30-minute post-exercise venous blood ammonium levels were observed in either the control subjects or patients with cirrhosis, whether the exercise was mild, moderate, or severe (Table II). In other words the venous blood ammonium concentration in both control subjects and patients with cirrhosis returned to the pre-exercise level within 30 minutes of completion of all grades of forearm exercise.

\section{Discussion}

The cirrhotic patients taking part in this study had a higher resting venous blood ammonium level than the control subjects. Mild exercise did not cause any significant elevation of blood ammonium concentration in either group (Allen and Conn, 1960, found a small increase in their cirrhotic patients). The release of ammonium by moderately exercising muscle occurred in all subjects but began earlier and was more prolonged in cirrhotic patients than in control subjects. After severe exercise both cirrhotic and noncirrhotic subjects exhibited equally large and prolonged releases of ammonium into the veins draining the forearm muscles. Pilot studies showed that there were no simultaneous increases of ammonium concentration in the venous blood draining the contralateral resting limb.

The greater release of ammonium in cirrhotic $\overrightarrow{\vec{F}}$ patients after moderate exercise requires explanation. Allen and Conn (1960) postulated that as cirrhotic patients frequently have higher blood $\overline{\bar{m}}$ ammonium levels than non-cirrhotics they may, $\underset{\mathbb{D}}{ }$ by virtue of continued uptake of ammonium by the peripheral tissues, accumulate ammonium in ${ }^{\text {s }}$ the muscles. The early release of ammonium $\overrightarrow{0}$ observed in cirrhotics in the present investigationmay simply reflect this saturation of voluntary $\bar{\rho}^{-}$ muscles with ammonium. There is no evidence to indicate that the release of ammonium during exercise is related to a change in the $p \mathrm{H}$ gradient between intracellular and extracellular fluid, $\infty$ carbon dioxide tension, the degree of oxygen $-\vec{T}$ saturation, the increase in blood flow thato accompanies muscular exercise, or the uptake of ${ }^{\supset}$ ammonium by the peripheral tissues (Allen and $\bar{Z}$ Conn, 1960).

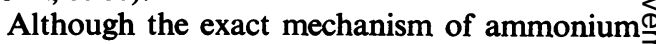
release after muscular exercise is not fully understood, its occurrence emphasizes the need to rest ${ }^{-1}$ subjects for at least half an hour before blood $\overrightarrow{0}$ sampling in order to avoid misleadingly higho readings. The phenomenon also indicates that the role of the peripheral tissues in ammonium metabolism must be carefully considered.

We wish to express our thanks to Mr D. W. Neill, consultant biochemist, Royal Victoria Hospital, Belfast, in whose laboratory the biochemical estimations were carried out, for his helpful criticism and advice; to Dr J. D. Merrett of the Department of Medical Statistics, The Queen'so University of Belfast, for criticism of the statistical methods used; and to Miss M. Weller for secre-尺 tarial assistance.

This work was supported by a grant from the Research Committee of the Royal Victorias Hospital and represents part of a thesis submitted을. by one of us (D.S.) and accepted for the degree of Doctor of Medicine by Trinity College, University" of Dublin.

\section{References}

Allen, S. I., and Conn, H. O. (1960). Observation on the effect of exercise on blood ammonia concentrations in man. Yale J. Biol. Med., 33, 133-144.

Bessman, S. P., and Bessman, A. N. (1955). The cerebral and peripheral uptake of ammonia in liver disease with an hypothesis for the mechanism of hepatic coma. J. clin Invest., 34, 622-628.

Bessman, S. P., and Bradley, J. E. (1955). Uptake of ammonia by muscle: its implications in ammoniagenic coma. Ne Engl. J. Med., 253, 1143-1147.

Kalk, H., and Boris, A. (1933). Úber den Ammoniakgehalt des Blutes nach Muskelarbeit. Z. Klim. med., 123, 731-741준 Cited by Allen, S. I., and Conn, H. O. (1960). Yale J. Biol Med., 33, 133-144. 
Luck, J. M., Thacker, G., and Marrack, J. (1925). Ammonia in the blood of epileptics. Brit. J. exp. Path., 6, 276-279.

McCullough, H. (1967). The determination of ammonia in whole blood by a direct colorimetric method. Clin. Chim. Acta, 17, 297-304.

Parnas, J. K., Mozolowski, W., and Lewinskiw, W. (1927). Über den Ammoniakgehalt und die Ammoniakbildung im Blut. 10. Der Zusammenhang des Blutammoniaks mit der Muskelarbeit. Biochem. Z., 188, 15-23.
Schwartz, A. E., Lawrence, W., Jr, and Roberts, K. E. (1958). Elevation of peripheral blood ammonia following muscular exercise. Proc. Soc. exp. Biol. (N.Y.), 98, 548-550.

Summerskill, W. H. J., Davidson, C. S., Dible, J. H., Mallory, G. K., Sherlock, S., Turner, M. D., and Wolfe, S. J. (1960). Cirrhosis of the liver. New Engl. J. Med., 262, 1-9.

Webster, L. T., Jr., and Gabuzda, G. J. (1958). Ammonium uptake by the extremities and brain in hepatic coma. J. clin. Invest., 37, 414-424.

\section{The October 1970 Issue}

\section{THE OCTOBER 1970 ISSUE CONTAINS THE FOLLOWING PAPERS}

Chromosomal aberrations in infective hepatitis N. MATSANIOTIS, K. KIOSSOGLOU, F. MAOUNIS, AND D. ANAGNOSTAKIS

An assessment of serum ${ }^{57} \mathrm{Co}$ cyanocobalamin as an index of vitamin $B_{12}$ absorption D. DONALDSON, B. J. N. BLIGHT, AND P. T. LASCELlES

Vitamin $\mathbf{B}_{12}$ absorption in some neurological and neuroendocrine disorders D. DONALDSON AND P. T. LASCELLES

Studies on the ${ }^{57} \mathrm{Co}$ vitamin $\mathrm{B}_{12}$ plasmal level absorption test B. K. ARMSTRONG AND H. J. WOODLIFF

Thermal damage to red cells S. BAAR AND D. J. ARROWSMITH

Pernicious anaemia among Arabs in Kuwait S. A. ALI, A. R. AL-YUSUF, S. N. SALEM, E. EL-GHAMRAWY, AND S. ZAGULAUL

Effect of feeding fat on fibrinolysis, Stypven time, and platelet aggregation in Africans, Asians, and Europeans J. C. FERGUSON, N. MACKAY, AND G. P. MCNICOL

Separation of the proteins of cerebrospinal fluid using gel electrofocusing followed by electrophoresis c. FOSSARD, G. DALE, AND A. L. LATNER

Alkaline phosphatase activity of polymorphonuclear leucocytes and lymphocytes separated from normal human blood JUDITH K. PARK

A fluorimetric and enzymatic method for the estimation of serum total bile acids G. M. MURPHY, BARBARA H. BILLING, AND D. N. BARON
The connective tissue in livers of children M. L. GHOSH AND J. L. EMERY

Cellular contamination during automatic and manual staining of cytological smears W. T. BARR, D. E. B. POWELL, AND J. B. RAFFAN

Ultrastructure of plasma cells containing Russell bodies in human stomach and thyroid A. GRAY AND I. DONIACH

Glomerular fine structure in mixed membranous and proliferative glomerulonephritis R. F. MACADAM

Rheumatoid heart disease with complete heart block M. HARRIS

Role of bacterial growth inhibitors in urine in diagnostic culture H. K. GHOSH

Elution of antibodies from biopsy tissue T. E. W. FELTKAMP AND J. H. BOODE

Studies on the laboratory diagnosis of human filariasis: Preliminary communication J. M. GOLDSMID

The double diffusion precipitin test in human fascioliasis PHILIP H. EVERALL

Technical methods

A simple method for histological examination of bone marrow particles using hydroxyethyl methacrylate embedding G. H. GREEN

Preparation of thin epoxy resin sections from thick sections of paraffin-embedded material J. BURNS

Letter to the Editor

Book reviews

Copies are still available and may be obtained from the PUBLISHING MANAGER, BRITISH MEDICAL ASSOCIATION, TAVISTOCK SQUARE, WC1H 9JR price 21 s. 